Eocene, south of the Gulf of Aden, a trifle when compared with the thickness of the sediments of a like age in the great geosynclines. In South-West Persia the Pliocene alone may be over 15,000 feet thick. In Tanganyika the geological column from Lower Jurassic to Miocene is contained within 2,000 feet of strata, and future workers may one day find every well-known fossil zone represented. Throughout this period the continent must have been here nearly at rest. But slow movements, consonant with these quiet conditions, were in some places in action at a quite early date. South of Abyssinia, in the Northern Frontier Province of Kenya near the borders of Jubuland, there is evidence that here the very earliest movements date from the Jurassic. Here the present upraised horsts may have been low islands in the Jurassic Sea. Similar evidence is available in the more easily accessible Mombasa District, where the old Jurassic shore-line, indented round the existing horsts, can be traced.

Thus the present geological evidence indicates quiet; an era of immobility, followed by gentle movements, spun out over long ages. Volcanic activity was probably equally spun out, but may have been initiated later than the first of the movements.

With the record of such a geological history it is difficult to see how the compression theory for rift valleys ever arose. It does not seem to have occurred to Gregory. Is it possibly the result of an urge to search for difficulties by those observers who do not like being surrounded by a grand plan of sublime simplicity? By a mere flight of steps we can descend from the simplicity that rules the major faulting of the valley sides, to the beautiful and unchallenged perfection of the normal faulting of "Sikes's Grid", in the floor of the Rift Valley itself in the Magadi District, or, as the writer often thinks of it, The Country of Gregory's Railway Platforms.

90 Great Russell Street, W.C.1.

\title{
ANNOUNCEMENT
}

\section{CLOUGH MEMORIAL RESEARCH FUND}

This fund was instituted in 1935, for the purpose of encouraging geological research in Scotland and the North of England. The North of England is defined as comprising the counties of Northumberland, Durham, Cumberland, Westmorland, and Yorkshire. Under the terms of administration of the Fund a sum of approximately $£ 30$ is available annually.

Applications for grants are invited for the period 1st April, 1945, to 31st March, 1946. These applications should state (1) the nature of the research to be undertaken; (2) the amount of grant desired; (3) the specific purpose for which the grant will be used, e.g. travelling expenses, maintenance in field, excavation of critical sections, etc. ; (4) whether any other grant-in-aid has been obtained or applied for.

Applications must be in the hands of the Secretary, Clough Memorial Research Fund Committee, Edinburgh Geological Society, Synod Hall, Castle Terrace, Edinburgh, not later than 1st March, 1945. 